IZA DP No. 8173

Search, Flows, Job Creations and Destructions

Pierre Cahuc

May 2014 


\title{
Search, Flows, Job Creations and Destructions
}

\author{
Pierre Cahuc \\ CREST-ENSAE, Ecole Polytechnique, \\ IZA and CEPR
}

Discussion Paper No. 8173

May 2014

IZA
P.O. Box 7240
53072 Bonn
Germany

Phone: +49-228-3894-0

Fax: +49-228-3894-180

E-mail: iza@iza.org

Any opinions expressed here are those of the author(s) and not those of IZA. Research published in this series may include views on policy, but the institute itself takes no institutional policy positions. The IZA research network is committed to the IZA Guiding Principles of Research Integrity.

The Institute for the Study of Labor (IZA) in Bonn is a local and virtual international research center and a place of communication between science, politics and business. IZA is an independent nonprofit organization supported by Deutsche Post Foundation. The center is associated with the University of Bonn and offers a stimulating research environment through its international network, workshops and conferences, data service, project support, research visits and doctoral program. IZA engages in (i) original and internationally competitive research in all fields of labor economics, (ii) development of policy concepts, and (iii) dissemination of research results and concepts to the interested public.

IZA Discussion Papers often represent preliminary work and are circulated to encourage discussion. Citation of such a paper should account for its provisional character. A revised version may be available directly from the author. 
IZA Discussion Paper No. 8173

May 2014

\section{ABSTRACT}

\section{Search, Flows, Job Creations and Destructions*}

This paper presents a short overview of dynamic models of labor markets with transaction costs. It shows that these models have deeply renewed the understanding of job search, job flows, job creations and destructions, unemployment and wage formation. It argues that this renewal provides a very useful toolkit for analyzing important economic policy issues such as the optimal level of unemployment benefits, the funding of unemployment insurance and the impact of employment protection legislation.

JEL Classification: J6, J31, J38

Keywords: job search, job flows, workers flows, unemployment

Corresponding author:

Pierre Cahuc

Laboratoire de Macroéconomie

CREST

15 Boulevard Gabriel Péri

92245 Malakoff Cedex

France

E-mail: pierre.cahuc@gmail.com

\footnotetext{
* This paper has been commissioned for presentation at Memorial sessions of the congress of the European Economic Association of Labor Economists, in September 2013, in Turin. It is forthcoming in Labour Economics. It owes much to the work accomplished with my co-authors, Stéphane Carcillo and André Zylberberg, when writing the textbook, Labor Economics, MIT Press, forthcoming, 2014. I also thank Joop Hartog, Kostas Tatsiramos and participants in the congress for their useful comments.
} 


\section{Introduction}

In 2010, The Royal Swedish Academy of Sciences awarded the "Nobel Prize" to Peter Diamond, Dale Mortensen and Christopher Pissarides "for their analysis of markets with search frictions". According to the Nobel prize committee, their contributions shed new light on fundamental questions: Why are so many people unemployed at the same time that there are a large number of job openings? How can economic policy affect unemployment?

In 1968, Friedman argued that there is a level of unemployment that cannot be changed by monetary policy in the long run. This "natural rate of unemployment, in other words, is the level that would be ground out by the Walrasian system of general equilibrium equations, provided there is embedded in them the actual structural characteristics of the labor and commodity markets, including market imperfections, stochastic variability in demands and supplies, the cost of gathering information about job vacancies and labor availabilities, the costs of mobility and so on" (Friedman, 1968, p8). But, at that time, almost nothing was known about the natural rate of unemployment. The dominant explanation of unemployment relied on the inflation-unemployment tradeoff in the Keynesian model enriched by the Phillips curve. As the inflation-unemployment tradeoff seemed to fade away, economists tried to go beyond the Keynesian model to explain unemployment. This led to a profound renewal of the conception of labor markets to which Diamond, Mortensen and Pissarides have been among the main contributors.

This renewal is deeply rooted in the discovery of new facts, which has shaken up the traditional conception of labor markets. The traditional conception relied on the static walrasian model. In this framework, labor markets are approximately efficient. This framework is useful to understand many phenomena, like the consequence of investment in human capital on wages, or the impact of taxes on wages and employment. However, it is not suitable to explain unemployment, the coexistence of unemployment and job vacancies and the consequences of the huge amounts of job and worker flows that exist in all labor markets. The renewal is more akin to the Schumpeter view, which is intrinsically dynamic and leads to the idea that labor markets are not spontaneously efficient. This created a new framework to think of the consequences about labor market institutions and labor market policies.

\section{New facts}

The unceased recomposition of jobs in market economies has a strong impact on labor markets. Full awareness of the extent of job creation and destruction is relatively recent. Only since the end of the 1980s have economists had available precise data covering sufficiently long periods about net employment changes, job flows and workers flows. 


\subsection{Jobs flows and workers flows}

Two kinds of data allow us to understand the dynamics of the labor market better. The first pertains to the processes of job creation and destruction, and the second to worker flows. Net variations in the volume of employment over a given period are equal, by definition, to the difference between job creations and job destructions over that period. They are also equal to the difference between workers' entries into and exits out of employment. In other words, variations in employment may be defined on the basis of the two following comparable identities:

$$
\text { Net employment change }=\underbrace{\text { Creations }- \text { Destructions }}_{\text {Job flows }}=\underbrace{\text { Hirings }- \text { Separations }}_{\text {Worker flows }}
$$

A surprise for researchers was the discovery that job flows were large and of the same order of magnitude in many industrialized countries (Davis, Faberman and Haltiwanger, 2006). To put it in a nutshell, we may speak appropriately of a "15\% rule," which may be stated as follows: on the national scale, around 15\% of jobs disappear every year, and every year around $15 \%$ of new jobs come into being.

Worker flows are even bigger than job flows. Workers' flows are different from job flows, for in addition to entries and exits linked to the creation and destruction of jobs, they also include rotations on the same job. A number of workers can in fact succeed one another in the same job. With data on French firms 1987-1990, Abowd et al. (1999) estimate that over the course of a year, the creation of one job corresponds to the hiring of three persons and the separation of two. As a general rule, workers' reallocations are clearly greater than those of jobs. Workers move from job to job, from unemployment to employment, they enter and exit from the labor force.

\subsection{Labor market flows and productivity}

Empirical research has shown that these large workers and jobs flows are induced by reorganization of the apparatus of production that may take the form of the creation of firms, the destruction of firms, or the reallocation of jobs between firms or within the same firm. For example, Foster et al. (2006) have analyzed the consequences of the evolution of economic activity undergone in the retail sector in the 1990s in the United States. During that period, the information technology revolution has had a strong impact on the retail sector. The adoption of systems that electronically link cash registers to scanners, credit card processing machines, customer relationship management systems and inventory management systems allowed establishments to increase labor productivity. Foster et al. (2006) find that virtually all of the labor productivity growth in the retail sector is accounted for by more productive entering establishments displacing much less productive exiting establishments.

More generally, research on the OECD countries shows that overall the process of creation and destruction of firms, as well as reallocations of production between firms, 
contribute significantly to the gains in labor productivity of the manufacturing sector over the period in question (OECD, 2003). This conclusion also holds good for the service sector, and for multifactor productivity growth (i.e. the Solow residual) rather than for labor productivity.

Productivity gains within firms are also related to labor turnover because they can be achieved by improving the productivity of the workforce in place, especially through training, but also by renewing it. It appears that firms which utilize information and communication technologies most intensively have higher manpower rotation. In total, firms with the highest productivity gains adopt a more dynamic style of workforce management, relying more heavily on internal promotion, and hiring and firing more frequently. This phenomenon is well illustrated by Bloom, Sadun and van Reenen (2012), who show that US multinationals have higher productivity from information and communication technologies than non-US multinationals, primarily due to their tougher "people management" practices, which include more intensive use of promotions, rewards, hirings and firings.

The finding of large job flows and workers flows induced economists to renew their conception of labor markets. Job creation and job destruction had to be conceptualized in a dynamic framework that accounts for and explains the unceased movements of workers and jobs.

\section{New theory}

The unceasing and massive movements of workers and jobs facilitates productivity growth. But it also creates unemployment, inequality, and exclusion. To a large extent, the process of job creation and destruction is at the center of the great economic and social problems of our time. The simultaneous presence of such high numbers of job created and destroyed caused economists to pay hommage to Joseph Schumpeter, who, though he had only scattered data to work with, had grasped as early as the 1940s that this process, which he called "creative destruction," was the principal driver of growth, but also one of the principal causes of unemployment. These ideas deeply renewed the conception of the labor market.

\subsection{The basic job search model}

The standard economic theory of labor supply pays no attention to the time and cost of looking for work. The consumption of "leisure", even when this term is extended to cover home production, remains the sole alternative to waged work. So from this perspective there is no place for the unemployed person whose principal activity amounts to looking for work. Such a description of the labor market assumes that each agent merely has to decide the number of hours that he wants to devote to work, given the single and universally known wage prevailing in the labor market. There is no need to look for a job that would suit him. To explain that unemployed workers need time to find jobs, 
economists had to account for consequences of imperfect information. This is precisely the purpose of job search theory: to study the behavior of an individual who has imperfect information about jobs and wages. The modern theory of the job search arose in the 1970s with the formalizations of McCall (1970) and Mortensen (1970). The job search model is useful to understand how the duration of the search depends on individual preferences, and the overall characteristics of the environment in which it takes place. This model is used in many applied contributions, relying on duration models, that evaluate the impact of passive and active labor market policies on unemployment duration and on the quality of jobs.

\subsection{The search and matching model}

In the 1980s and the 1990s new models have nested the basic job search model, that represents the behavior of individuals looking for jobs, in a framework that also accounts for the behavior of firms and its interations with that of workers. These models, developed by Diamond, Mortensen and Pissarides, account for labor market frictions, i.e. the fact that there is a lack of information which implies that workers have to search to find jobs and firms must search to fill their vacant jobs. The search process requires time. Accordingly, jobs and workers do not meet instantly. There are both job vacancies and unemployment on the labor market.

The search and matching model is the workhorse of most modern analyses in macro labor. This model envisages the hiring process as a phenomenon of matches between employers and workers. In this framework, the probability for every unemployed person to receive a job offer suited to her abilities depends on the tightness prevailing in the labor market, i.e. the ratio of the number of vacant jobs to the number of unemployed persons. If this ratio is high (many vacant jobs, few job-seekers), every unemployed person has a high probability of finding a job. Symmetrically, each person's probability of finding and filling a vacant job has to decrease when this ratio decreases (few vacant jobs, many job-seekers). This representation of the process of matching up jobs and workers, developed especially by Hall (1979) and Pissarides (1979, 2000), makes it possible to grasp the determinants of unemployment in a dynamic environment where jobs are created and destroyed continually, and in which there are transaction costs attached to reallocating employment.

This model allows economists to study many phenomena such as the impact of productivity shocks and of technological progress on unemployment. It also sheds some new lights on the roots of labor market inefficiencies.

\subsection{Labor market efficiency}

In the search and matching model, the decentralized equilibrium is generally inefficient contrary to that of the walrasian model. The inefficiency of the decentralized equilibrium stems from transaction costs which induce trading externalities. If the number of vacant jobs rises, each vacant job has a smaller probability of being matched with a worker, but 
each unemployed person has a higher probability of finding a job. Firms prefer to compete with as few vacant jobs as possible, so that their vacant jobs will be filled as rapidly as possible, but unemployed persons prefer the inverse: that there should be many vacant jobs, so as to increase their likelihood of being hired. Correspondingly, if the number of unemployed persons rises, each of them has fewer chances of finding a job, while firms see their chances of being able to fill their vacant positions increase. To put it in summary fashion: every unemployed person would like to be the only member of that category, and would like the category of vacant jobs facing him to be as full as possible, while every employer would like to be the only one with positions vacant, and to be facing a wide array of job seekers. There are congestion effects within each category and positive externalities between the categories.

An omniscient planner who wished to maximize efficiency would internalize these externalities and would arrive at a social optimum in which the congestion effects and the positive externalities would be "blended" in the manner that best met her choice criterion. Now, firms and workers do not internalize these externalities, and the decentralized equilibrium of the labor market is not required a priori to correspond to a social optimum, except under very specific situations, where the bargaining power of workers in wage negotiations fulfills the Hosios-Pissarides condition ${ }^{1}$ (in the random search model, Pissarides, 2000) or where workers are perfectly mobile across local labor markets (in the directed search model, Moene, 1997).

All in all, the search and matching model represents a "second-best" world, that allowed economists to renew the analysis of the consequences of labor market policies, such as the minimum wage, unemployment insurance, employment protection legislation and active labor market policies.

\subsection{Wage dispersion}

In a perfectly competitive labor market, with given productive abilities and working conditions, the wage of any individual ought to be independent of the firm or industry in which she is employed. If one industry or firm pays better than others, perfect mobility of workers ought to lead to a flow of labor supply toward that firm or industry, and a consequent drop in remuneration. But empirical studies (Abowd et al., 1999, Abowd et al., 2013) show that individuals with identical time-invariant characteristics are paid differently when they work in different firms. The interpretation of these results is a delicate matter. It is possible that wage differences among firms may be the result of unobserved differences linked to working conditions on a perfectly competitive labor market. The compensating differential theory of wages indicates that a wage reflects not just productive ability, but also the content of the tasks an employee must carry out at her workplace: more dangerous, more unstable, and more laborious jobs are offset by higher wages. As

\footnotetext{
${ }^{1}$ The Hosios-Pissarides condition states that the decentralized equilibrium is efficient if the bargaining power parameter of the Nash bargaining solution equals the elasticity of the matching function with respect to unemployment.
} 
these characteristics of jobs are generally poorly measured, it remains possible that the unobserved heterogeneity of jobs does explain wage differences among firms, according to a perfectly competitive logic.

Search and matching models show that the dispersion of wages may also be the consequence of labor market imperfection. Mobility costs and the rent-sharing that attends them generate wage differentials that are unrelated to productivity differentials and that hinder the efficiency of the competitive mechanism. These models have made a profound advance in our conception of wage formation.

When job search theory emerged, Diamond (1971) criticized its consistency by arguing that rational firms should pay workers their reservation wage. Thus, according to "Diamond's critique", if the reactions of employers are introduced into the basic job search model, the outcome is necessarily a labor market equilibrium in which the distribution of wages is concentrated at a single point, equal to the reservation wage. At first sight, Diamond's critique appears to deprive the basic job search model of all its relevance, since within this model we cannot explain why the distribution of wages does not degenerate to a single point.

However, Burdett and Mortensen (1998) have shown that on-the-job search models, which account for job-to-job mobility, can explain wage dispersion. They show that competition between employers to attract workers who can search on-the-job can imply that identical workers can get different wages in different firms. More recent work by Hornstein et al. (2011) shows that the basic job search model does predict a narrow dispersion of wages but that accounting for job-to-job mobility can explain that identical workers can be paid very differently depending on the firms where they work.

The search and matching model with on-the-job search yields a certain number of pertinent empirical predictions (Postel-Vinay and Robin, 2002).

First, in the equilibrium search model, the wage of an individual employee rises when she moves from one job to another. Although that is not in practice the only reason for individual pay to rise, this phenomenon is in fact observed in the majority of transitions of this type. Moreover, in this model, since firms that set higher wages are able to attract and to retain more workers, the wage is positively correlated with the size of the firm, which fits well with observations that tell us that, even after controlling for the heterogeneity of workers and firms, bigger firms pay higher wages than do smaller ones.

Second, wages rise, on average, as workers gain experience. Assuming that new entrants begin as job-seekers, the wage at which they are hired is a minimum corresponding to the reservation wage. After that, their wage rises every time they change firms. More senior employees, who have on average had the most job offers, thus enjoy the highest wages. This prediction of the equilibrium search model agrees with the observation that a worker's wage increases with the time she has spent in the labor market.

Third, the lower bound of the equilibrium wage distribution being equal to the reservation wage, an unemployed job-seeker accepts all the offers he receives. This conclusion fits very well with that of empirical studies, which do in fact find that the probability of accepting an offer is close to 1. 
Fourth, the on-the-job search model with sequential auction and wage bargaining provides a good fit of the empirical distribution of wages across workers (Cahuc et al., 2006).

\section{Is it useful for policy makers?}

As we have seen, research on search and labor flows induced a large and profound renewal of the conception of labor markets. Over the last twenty years, labor economists have much improved their understanding of the process of job creation and job destruction and of the role of transaction costs. This renewal had an impact on the conception of many policies, such as the minimum wage, unemployment insurance, employment protection legislation and active labor market policies. Let us see what policy makers can learn from this renewal in two realms most related to job creation and job destruction: unemployment insurance and employment protection legislation.

\subsection{Unemployment insurance}

What is the appropriate level of unemployment benefits? Should unemployment benefits decrease with the unemployment spell? What are the effects of job search assistance on unemployment durations? Do training policies really help unemployed workers to find jobs? What is the impact of monitoring of obligations in order to receive unemployment benefits on unemployment spells?

Knowing the answers to these questions is primordial to be able to design unemployment insurance. The knowledge of the behavior of unemployed workers is indeed essential to implement efficient unemployment insurance in a context where most often the agency managing the unemployment insurance system cannot check thoroughly on whether the unemployed persons are making suitable efforts to find a job. The agency is faced with a "moral hazard" problem, and perfect insurance, i.e. complete replacement of the unemployed person's lost income, might also take away his or her incentive actively to look for a job.

Theoretical and empirical contributions have brought some important results in this

field. In particular they have analyzed the determinants of unemployment spells and of of post-unemployment outcomes (see Tatsiramos and van Ours, 2013, for a recent survey).

Unemployment durations and post employment outcomes

Empirical studies find that potential benefit duration and the replacement rate exert significant effects on the duration of unemployment. The magnitude of the effects of unemployment benefits differs for different countries and different types of policy changes. Nevertheless, one can keep in mind the two following orders of magnitude: first, the elasticity of the duration of unemployment with respect to the replacement ratio varies between 0.4 and 1.6; and second, an increase of a week in the potential duration of benefit 
payments leads to an increase in the duration of unemployment ranging between 0.1 and 0.4 of a week.

The job search model predicts that an increase in the amount of unemployment benefit or in its potential duration ought, by raising the reservation wage, to entail an improvement in the quality of the jobs accepted by the unemployed. The first researches published on this topic show that the generosity of unemployment insurance had a positive impact on the wages of jobs accepted upon exit from unemployment. It is also found that the jobs accepted at the close of the potential duration of unemployment insurance are more unstable, and on the other hand that a higher replacement ratio leads to more stable jobs.

Recent empirical studies also arrive at convergent results regarding the effects of wealth and liquidity constraints. For instance, Chetty (2008) finds that the link between between unemployment benefits and unemployment duration is driven by a subset of the population that has limited ability to smooth consumption. This pattern is suggestive of a substantial liquidity effect, which might explain 60 percent of the marginal effect of unemployment insurance benefits on unemployment duration at current benefit rates in the United States. But there are not yet sufficiently numerous contributions in this field to yield definitive conclusions.

\section{Helping and monitoring the unemployed}

The majority of OECD countries have adopted measures aimed at increasing the efficiency of the job search by those receiving unemployment insurance benefits. In the United States, Denmark, the Netherlands, and the United Kingdom, starting in the 1980s, these measures combine help in looking for a job with sanctions, generally consisting of a reduction in benefit, when the rules imposed by the body administering unemployment insurance are not adhered to. Studies of experimental and non-experimental programs usually find that the surveillance and counselling programs may have a significant effect on unemployment exit rates among those who need help. They also exert pressure on a percentage of the eligible unemployed who are not experiencing any real difficulty in finding work.

\section{Optimal level unemployment benefits}

Research on optimal unemployment insurance, relying on the seminal paper of Bailly (1978), shows that it is possible to characterize the optimal level of unemployment benefits using a limited set of parameters that summarizes the behavior and/or the preferences of unemployed workers.

For instance, in the contribution of Baily (1978), the optimal level of unemployment benefits can be defined from the knowledge of the elasticity of unemployment duration with respect to unemployment benefits, the relative risk aversion and the gap between the consumption of unemployed workers and employees. The difficulties encountered when estimating some of these parameters, especially risk aversion, led researchers to look for other formulas defining the optimal level of unemployment benefits. Chetty (2008) provided a formula that defines the optimal replacement ratio as a function of the elasticity of 
unemployment spell with respect to the liquid wealth and with respect to the unemployment benefits. Shimer and Werning (2007) supplied an alternative formula, which allows them to define the optimal level of unemployment benefits as a function of the elasticities of the reservation wage and of the unemployment spell with respect to unemployment benefits.

This strand of research proves useful to evaluate the optimal level of unemployment benefits. For instance, Chetty (2008) concludes that the actual replacement ratio in the US economy, which corresponds roughly to a benefit equal to 50 percent of the preunemployment wage for 6 months, is near optimal, in the context of the US economy. Shimer and Wernig (2007) reach a somewhat different conclusion, according to which unemployment benefits are (a little) too low in the US economy. These results are particularly relevant to policy markers. However, much progress is still needed. The orders of magnitude about the key parameters are still very imprecise. Much research is needed to provide precise estimates, depending on the context of each policy.

Time profile of unemployment benefits

Another issue of interest is the time profile of unemployment benefits. Indeed, a relevant analysis of unemployment insurance should focus on the time profile of the benefit payments, which can provide at least as much incentive as their amount. This is the reason most unemployment insurance systems limit the period during which the unemployed can receive benefits, and provide for such benefits to tail off the longer that period lasts. The dynamic job models with moral hazard and job search of Shavell and Weiss (1979), Hopenhayn and Nicolini $(1997,2009)$ do in fact prove that optimal unemployment benefits must necessarily decrease with the length of the unemployment spell. However, calibration exercises suggest that declining profiles provide only very small welfare gains when the unemployment insurance agency can tax and subsidize wages. Moreover, Shimer and Werning (2008) have shown that the optimal timing can be either increasing or decreasing with the unemployment spell when workers can save and borrow and have free access to a riskless asset. In their set-up, a constant benefit during unemployment is optimal when workers have a constant absolute risk aversion.

These contributions underline the potential importance of the ways unemployment insurance systems are structured when moral hazard is present. Wang and Williamson (2002) have extended the job search model by assuming that the probability of employment loss depends on the effort made by employees. In this hypothesis, moral hazard extends not just to the search efforts of the unemployed, but also to the assiduousness at work of those who are employed, for they may be tempted to shirk in order to lose their jobs if unemployment insurance benefits are too high. It is therefore desirable to adopt an experience rating scheme, in which wages can be taxed, and where income received depends on the duration not just of spells of unemployment, but also of employment.

Unemployment insurance and the business cycle 
Reflections about optimal unemployment insurance indicate that unemployment benefits should depend on the economic context. From this perspective, it is possible that optimal unemployment benefits should vary over the cycle. Indeed, theory shows that the insurance value of unemployment insurance is higher in periods with high unemployment. Moreover, it is also possible that the disincentive effects of unemployment benefits are smaller in periods with high unemployment if the elasticity of unemployment spell with respect to unemployment benefits is smaller during downturns. Therefore, both insurance and incentive arguments may go in the direction of supporting counter-cyclical unemployment insurance generosity. Such schemes do exist in the United States and in Canada.

Empirical studies provide some evidence suggesting that explicit business cycle contingencies in the unemployment insurance scheme can contribute to a system which provides more insurance when it is most needed at the same time as the incentive structure is strengthened by reducing benefit generosity when it is most distortionary. Relying on US data over the period 1985-2000, Kroft and Notowidigdo (2011) find that the elasticity of unemployment duration with respect to the level of unemployment benefits is smaller when the local unemployment rate is higher. Landais (2013) reaches similar conclusions using other data sets for the US.

All these analyses are in a partial equilibrium framework, that does not account for the impact of policies on job creation. Related analyses in stochastic dynamic search and matching models with endogenous job creation suggest that active labor market policies should also vary over the business cycle. Jung and Kuester (2013) show that optimal policies should combine vacancy subsidies, layoff tax and unemployment benefits that increase during downturns.

All in all, researches on job search allowed economists to provide many advices, relying on theoretical and empirical findings, to implement unemployment insurance systems that aim at reaching the right balance between insurance and incentives. However, much remains to do. Economists are still unable to provide advices relying on reliable knowledge on many important issues. In particular, economists know very little about the consequences of eligibility rules that define the conditions needed to be fulfilled to get unemployment benefits; economists also know very little about the consequences of short time work, that allows individuals to work part time while getting unemployment benefits.

\subsection{Employment protection legislation}

Employment protection legislations are mandatory rules that restrict the dismissals of employees. They are widepreads among most countries. Their stated purpose is to increase the stability of employment. Despite that, there is intense debate about their actual effects, which also influence the level of employment and labor productivity. Over the last two decades, numerous studies have shown that employment protection legislations have strong impact on labor markets flows and productivity. Theoretical and empirical contributions 
have been useful to elaborate normative proposals.

The effects of employment protection legislation in search and matching models

Theoretical analysis, relying on search and matching models, has greatly improved our understanding of the consequences of job protection legislations. These analyses do indeed suggest that employment protection has large-scale effects on workers and job flows. The effects on these flows depend on the context. Job protection of open-ended contracts reduces the turnover of these contrats: there are less entries and less exits when job protection is more stringent. However, this type of protection has side effects to the extent that more stringent job protection goes hand in hand with the spread of fixed term jobs. When it becomes more difficult to dismiss workers on open-ended contracts, firms use fixed-term contracts instead. This substitution of fixed term jobs to open-ended jobs increases labor turnover. It induces labor market segmentation between temporary and permanent jobs, with excessive churning of temporary workers which counteracts the stabilizing effects of job protection on open-ended jobs. Accordingly, the overall impact of employment protection legislations on job stability can be either positive or negative, depending on the specificities of each legislation concerning the regulation of open-ended and fixed-term contracts.

Search and matching models also show that whether employment protection legislation pushes unemployment up or down remains ambiguous. It depends especially on the wage setting process. When wages are downward rigid, which is the case when there is a binding minimum wage, job protection strongly increases the unemployment rate. However, when wages are flexible, the impact of job protection on the unemployment rate is ambiguous, because wages drop when job protection becomes more stringent. Theory also predicts that employment protection legislation reduces labor market participation to the extent that employment protection legislations are similar to taxes on the surplus of jobs. Finally, theory shows that job protection mostly decreases labor productivity because it mitigates the reallocation of jobs toward more productive activities and it reduces the possibility to use layoff as an incentive device for employers.

What empirical studies tell us

Assessment of the impact of employment protection remains primarily an empirical question. Much research has tackled this problem since the 1990s. A first strand of research analyzed cross-country correlations between unemployment and various indicators of employment protection legislation. This research generally finds positive correlations between employment protection and unemployment. However, these results should be interpreted cautiously because changes in employment protection legislation and changes in unemployment can be co-determined by common factors.

A second group of more recent contributions, developed in the 2000s, used data at the level of the industry, or at the level of the firm, or at the individual level, that allows for better identifications of the impact of labor market regulations on employment outcomes. In some cases, reforms of employment protection legislations were targeted at subgroups 
in the labor force, providing researchers with a natural experiment in which outcomes can be compared across subgroups. These studies find negative effects of job protection on employment and labor flows. For instance, Autor et al. (2006) estimate the effects on employment and wages of wrongful discharge protections adopted by U.S. state courts. They find that wrongful discharge protections reduced state employment rates by 0.8 percent to 1.7 percent. The initial impact is largest for female and less-educated workers, while the longer-term effect is greater for older and more-educated workers.

All in all, studies using microeconomic data find that more rigorous employment protection reduces employment and labor productivity. More stringent employment protection also increases labor market segmentation because firms do use more temporary jobs when protection of permanent jobs is stronger in order to adapt employment to changes in production. These findings lead many economists to consider that stringent job protection legislations, which rely on mandatory rules generally implemented under the control of judges, are mostly inefficient. However, as we are going to see now, this does not mean that any form of employment protection is worthless.

\section{The efficiency of employment protection legislations}

To the extent that the incessant process of job creation and destruction contributes to growth, when a job vanishes, it is not a loss for the collectivity, although it generally is for the person who held that job. Legislation that prevented the destruction would by the same token have prevented a collective advantage from being realized. But conversely there are other reasons that weigh in favor of preserving certain jobs which firms might want to destroy because the decision to destroy a job can have repercussions going well beyond the interests of the firm and the worker alone.

One reason is the need to protect workers from arbitrary dismissals, which is covered by the regulation of individual dismissals, according to which dismissal for reasons relating to the individual employee is justified only if the employee is guilty of breaking or failing to fulfil a contractual obligation. This is the just cause doctrine, adopted in European countries, which states that firms cannot dismiss employees without showing just cause. The just cause doctrine is justified by the fact that mobility costs, imperfect information, myopic behaviors, contract incompleteness, do not allow workers to fully benefit from competition between firms. When market are not perfectly competitive, employment protection legislation can be useful to protect workers against the arbitrary decisions of employers. For instance, an employer who does not comply with health and safety regulations in the workplace may fire workers who complain. The employer may have an interest to do so if he has monopsony power which allows him to replace those workers at low cost. Enacting a regulation which protects workers against such layoffs may improve efficiency. One must admit that economic analysis still provides very limited knowledge on this issue.

However, empirical research has shown that even if there are justifications for just cause, job protection legislations should be elaborated cautiously because they can have perverse effects. For instance, Acemoglu and Angrist (2001) have studied the conse- 
quences of the Americans with Disabilities Act, which requires employers to accommodate disabled workers and outlaws discrimination against the disabled in hiring, firing, and pay. Although the Americans with Disabilities Act was meant to increase the employment of the disabled, the net theoretical effects are ambiguous, because employers may have ways to avoid recruiting disabled employees. Actually, it seems that the Americans with Disabilities Act has had an effect exactly opposite to its goal: for men of all working ages and women under 40, Acemoglu and Angrist find a sharp drop in the employment of disabled workers after the Americans with Disabilities Act went into effect.

Employment protection legislations and unemployment insurance

Another reason to regulate job destruction is that job destruction can be a source of externalities. This case arises when the value of a job for the collectivity, its social value, does not coincide with its private value. The social value is measured by the sum of the private value plus the value of the externalities.

One important cause of the gap between the social value and the private value of a job lies in unemployment insurance and all forms of welfare. In most industrialized countries, unemployment insurance is financed by a tax based on wages, which is paid in varying proportions by both employees and employers; it is one component of what are collectively called payroll taxes. Under an efficient system of unemployment insurance, an employer who lets an employee go would have to take into account the externality arising from the financing of the unemployment insurance benefit then paid to that worker by other wage-earners and other employers through their contributions to unemployment insurance.

Blanchard and Tirole (2007) have shown that financing unemployment insurance with layoff taxes induces employers to internalize these externalities. This leads to recommend to substitute layoff taxes, used to finance unemployment benefits, and also welfare expenditures (Cahuc and Zylberberg, 2008), for employment protection legislations relying on mandatory rules implemented under the control of judges. ${ }^{2}$ It is worth noting that a bonus-malus mechanism exists in the United States, where charges associated with the payment of unemployment benefits are assigned to employers through "experience rating." Employers who initiate comparatively more job separations and thus increase the burden on the unemployment insurance system must pay higher unemployment insurance contributions than those that initiate fewer separations.

The single open-ended contract and flexicurity

A related recommendation is to substitute a single open-ended contract, including layoff taxes increasing with contract duration, for the menu of fixed-term and open-ended contracts encountered in countries with stringent employment protection legislation (Bentolila et al. 2010). This proposal aims at substituting fiscalization of job protection for employment protection regulations that are justified neither by the protection against arbitrary dismissals nor by externalities associated with job destruction. Indeed, several

\footnotetext{
${ }^{2}$ As stressed by Cahuc and Zylberberg (2008) and Jung and Kuester (2013), in this context, it is optimal to use hiring subsidies to counteract the negative impact of layoff taxes on job creation.
} 
features of employment protection legislation in many countries have hardly anything to do with the justifications of employment protection legislation that have been put forward by economic analysis. Some rules protect permanent workers, over-represented in trade unions relative to temporary workers and unemployed workers. However, these rules neither protect workers from arbitrary dismissals nor induce employers to internalize the social cost of layoffs in an efficient way. These rules comprise, for instance, the order of selection of layoffs in case of redundancy, the rehiring priority and the obligations made on the internal reassignment of employees.

Substituting fiscalization of job protection for the set of rules which impose the order of selection of layoffs in case of redundancy, the rehiring priority and the obligations made on the internal reassignment of employees is a means to allow employers to manage their manpower efficiently, to induce them to take into account the social costs of layoffs, and also to provide funding to unemployment insurance and to public employment services. The logic of fiscalizing employment protection thus lies in taxing job destructions while providing more generous and more efficient unemployment insurance. This is why the fiscalization of employment protection reconciles both employers' and workers' needs, flexibility and security, by ensuring the worker safe transitions inside the labor market, while maintaining and improving competitiveness of the companies. Moreover, the fiscalization of employment protection allows us to get rid of the labor market segmentation induced by rigid rules imposed on layoffs for economic reasons. By making firing taxes depending on the social cost induced by workers turnover, whatever the form of labor contract, either temporary or permanent, it is possible to avoid the gap between jobs with different status, which gives rise to inefficient labor turnover. This corresponds to the founding principles of the "flexicurity model", which inspired the Danish labor market regulation and which is endorsed by the European Commission (Boeri et al. 2007).

\section{$5 \quad$ What should be done?}

During the last two decades, an impressive amount of empirical and theoretical research has been devoted to the search and matching models and to the exploration of job and worker flows. However, much remains to be done in this field which is far from being drained.

\subsection{Theory}

Economics needs good models that fit, to a reasonable approximation, certain important stylized facts. From this perspective, the search and matching model is not exempt from criticisms. In particular, Shimer (2005) argued that the matching model cannot reproduce unemployment dynamics well, because any productivity shock is immediately absorbed into the wage with little effect on unemployment. Hence, in comparison to observed fluctuations, the matching model would generate too much volatility for the real wage and 
not enough for the unemployment rate. This is the so called the "unemployment volatility puzzle."

A range of solutions have been put forward to the "unemployment volatility puzzle." The first assigns a high value to non-market activity, the second attempts to make wages more rigid, the third draws a distinction between the wage rigidity of employees in place and the wage rigidity of new entrants, while a fourth solution is based on the heterogeneity of jobs.

Hagedorn and Manovskii (2008) have proposed a model in which the instantaneous income of the unemployed is high, and in which they have little bargaining power. The high value of the instantaneous income of the unemployed is justified by the high value of non-market activity. In this setting, the matching model correctly reproduces the elasticity of the exit rate from unemployment with respect to productivity.

Many researchers have tried to explain unemployment volatility by wage rigidity. Hall and Milgrom (2008) modify the threat point in Nash bargaining by assuming that it is possible to prolong the bargaining. The threat is then no longer that the work relationship will be broken off, but that time and production will be wasted during the bargaining. The empirical data assembled by Hall and Milgrom show that the value of the time and production wasted in bargaining is less cyclical than the dissolution value of the job, which corresponds to the discounted expected utility of unemployed workers. In consequence, in the model of Hall and Milgrom the wage reacts less to variations in productivity, which entails greater volatility in the unemployment rate. Kennan (2010) reaches a similar conclusion with a framework that provides another explanation for wage rigidity. He assumes that productivity is subject to publicly observed aggregate shocks, and to idiosyncratic shocks that are seen only by the employer. Kennan shows that small fluctuations in productivity that are privately observed by employers can give rise to a kind of wage stickiness in equilibrium, and the informational rents associated with this stickiness are sufficient to generate relatively large unemployment fluctuations.

Pissarides (2009) notes that the wage stickiness highlighted by empirical research is a property of the average wage. It does not apply to all wages. When we concentrate on the wages of employees who are starting new jobs (movers), wage stickiness looks a lot different than it does when we examine the wages of those who have remained in the same job for a while (stayers). The interpretation of the empirical research advanced by Pissarides (2009) and his own estimates indicate that, in the United States, the unemployment wage elasticity of movers is at least equal to 1 , whereas it would lie between 0.3 and 0.5 for the stayers. The calculations of Robin (2011) confirm this observation. They indicate that wage elasticities differ according to deciles. For men for example, wage elasticity amounts to 0.92 for the bottom decile - where the majority of starting wages lie -, and to around 0.40 in the middle of the distribution.

Previous explanations of the unemployment volatility puzzle rely on a matching model that leaves out the heterogeneity of jobs and movements from job to job. Menzio and Shi (2011) and Robin (2011) have looked at the consequences of aggregate productivity shocks in models with heterogeneous jobs and on-the-job search. In these models, aggregate 
productivity shocks affect movement from job to job, and have a major impact on the destruction and creation of low-productivity jobs, with no need to advance any hypothesis about wage rigidity.

Elsby and Michael (2013) have studied labor market dynamics with a model including large firms. Due to the diminishing marginal product of labor, the model simultaneously generates a large average surplus and a small marginal surplus to employment relationships. The small marginal surplus to employment relationships allows their model to match the volatility of the job-finding rate over the cycle, whereas the large value of the average surplus allows their model to match the rate of entries into unemployment. This is progress with respect to the strategy that assumes a small job surplus to generate enough cyclicality in job creation in the standard matching model, because assuming small job surplus with constant marginal returns to labor yields excessive employment-to-unemployment transitions. The calibrated version of the model of Elsby and Michael (2013) provides a coherent account of the distributions of firm size and employment growth, the amplitude and propagation of the cyclical dynamics of worker flows, the Beveridge curve relation between unemployment and vacancies, and the dynamics of the distribution of firm size over the business cycle.

On the whole, research on the unemployment volatility puzzle tells us that the matching model is capable of reproducing the relation between productivity and unemployment. There is not, however, any consensus about which hypotheses are most pertinent when it comes to reproducing this relation. More research is needed in this realm.

\subsection{Empirical estimates of transaction costs}

Transaction costs play a central role in the analysis of the consequences of job flows. However, their empirical evaluation is insufficient. Transactions costs are generally accounted for by the matching function, which represents the number of matches between job vacancies and unemployed workers. The matching function can be estimated on the basis of time series data on hires, job vacancies and unemployment. Most often the estimation uses simple OLS regressions where the left hand side variable is the logarithm of the exit rate from unemployment and the right hand side variables comprise the labor market tightness, equal to the ratio of vacancies over unemployment. For instance, using a simple OLS regression based on monthly data covering the period 2001-2009 for the United States, Rogerson and Shimer (2011) find an elasticity of the exit rate from unemployment with respect to labor market tightness equal to 0.58. It turns out that the incidence of long term unemployment, the geographical dispersion of vacant jobs and unemployed persons, and the demographic structure of the labor force also exert significant influence on the matching process.

Borowczyk-Martins et al. (2013) have noted however that estimations based on simple OLS regressions are probably biased, since the decision to post a job vacancy is not independent of the efficiency of the matching process. Firms may have an incentive to create more vacant jobs when the efficiency of the matching process improves, for it means 
they can hire more rapidly.

The content of these contributions shows that, actually, the evaluation of the contribution of transactions costs to unemployment is still in its enfancy. Not much is known about it and innovative research is needed.

\subsection{Data on workers and jobs}

One of the main contributions of the literature on labor market flows has been to reveal their quantitative importance. The annual number of entries into employment can be twice as high as the stock of employment when all entries, including very short employment spells, are accounted for. It appears that there are many very short (below one month) employment spells. Better data are needed to gauge these very high frequency movements. Labor force surveys, that survey individuals at quarterly frequency, provide only very partial information about these movements. Surveys that follow individuals daily would be needed to gather appropriate information. It is necessary to track individuals during their successive periods of employment, unemployment and inactivity. Most surveys do not allow to do this at high frequency. Information at high frequency on the side of the firm is also needed. And finally, matching high frequency information on firms and individuals is essential to have a full description of labor market flows. Such high frequency matched firm-employer data are missing.

\section{Conclusion}

Over the last two decades, research on job search, flows, job creation and destruction has induced labor economists to give up the static walrasian conception of the labor market at the benefits of Schumpeter's one. This change was necessary to better explain unemployment, which is one of the main concerns of policy makers when they think about labor markets.

Since the start of this research program, in the 1970s, a long road has been traveled. ${ }^{3}$

Now, the natural rate of unemployment, which was a vague concept, can be explained with models that account for transaction costs in a dynamic framework. These models allow economists to analyze the influence of many phenomena such as wage formation, unemployment benefits, job protection, technological progress and the nature of job reallocation on unemployment. It is remarkable that most of these models are developed in the framework shaped by Diamond, Mortensen and Pissarides in the 1970s, who impulsed an almost "linear" development of the theory until now.

The development of dynamic models of labor markets with transaction costs did not only enrich the understanding of unemployment. The new dynamic theory clearly explains old questions better than the old static theory, and explains phenomena that before could not be explained, such as job creation and destruction, the coexistence of job vacancies and

\footnotetext{
${ }^{3}$ See the converging views of Bertil Holmlund (2014) in this volume.
} 
unemployment, workers flows, unemployment duration and wage dispersion of identical workers.

This renewal provides a very useful toolkit for analyzing important economic policy issues such as the optimal level of unemployment benefits, the funding of unemployment insurance, the impact of employment protection legislation. From this perspective, there is little doubt that this research has had a profound influence on labor market institutions such as unemployment insurance and employment protection legislations. However, this research is still in its infancy. Much remains to be done. We need better data and models that fit the data better to provide relevant answers to the many questions addressed by policy makers. 


\section{References}

Abowd, J.M., Kramarz, F., Lengermann, P., Mc Kinney, K., and Roux, S. (2013), "Persistent Inter-Industry Wage Differences: Rent-Sharing and Opportunity Costs," IZA Journal of Labor Economics.

Abowd, J., Kramarz, F. and Margolis, D. (1999), "High Wage Workers and High Wage Firms", Econometrica, 67, pp. 251-334.

Acemoglu, D. and Angrist, J. (2001), "Consequences of Employment Protection: The Case of the Americans with Disabilities Act", Journal of Political Economy, 109, pp. 915-957

Autor, D., Donohue, J. and Schwab, S. (2006), "The Costs of Wrongful-Discharge Laws", The Review of Economics and Statistics, 88(2), pp 211-231.

Baily, M. (1978), "Some Aspects of Optimal Unemployment Insurance", Journal of Public Economics, 10, pp. 379-402.

Bentolila .S., Boeri, T. and Cahuc, P. (2010), "Ending the scourge of dual labour markets in Europe", VoxEU.org, 12 July.

Blanchard, O. and Tirole, J. (2007), "The Optimal Design of Unemployment Insurance and Employment Protection: A First Pass ", Journal of the European Economic Association, 6(1), pp. $45-77$.

Bloom, N., Sadun, R. and Van Reenen, J. (2012) "Americans do IT better: US multinationals and the productivity miracle." American economic review, vol 102 (1), pp. 167-201.

Boeri, T., Cahuc, P., Crnkovic, S., Kollonay-Lehoczky, C. and Wilthagen, T. (2007) Flexicurity Pathways, Turning Hurdles into Stepping Stones. Brussels: Report by the European Expert group on Flexicurity.

Borowczyk-Martins, D., Jolivet, G. and Postel-Vinay, F. (2012) "Accounting For Endogeneity in Matching Function Estimation", Forthcoming Review of Economic Dynamics.

Burdett, K. and Mortensen, D. (1998), "Wage differentials, employer size, and unemployment", International Economic Review, 39, pp. 257-273.

Cahuc, P., Postel-Vinay, F. and Robin, J.-M. (2006), "Wage Bargaining with On-the-Job Search: Theory and Evidence," Econometrica, 74(2), pp. 323-364.

Cahuc, P. and Zylberberg, A. (2008) "Optimum Taxation and Layoff Taxes, with André Zylberberg, Journal of Public Economics, 92, pp. 2003-2019. 
Chetty, R. (2008), "Moral Hazard vs. Liquidity and Optimal Unemployment Insurance Journal of Political Economy, 116(2), pp. 173-234.

Davis, S., Faberman, J. and Haltiwanger, J. (2006), "The Flow Approach to Labor Markets: New Data Sources and Micro-Macro Links", The Journal of Economic Perspectives, 20(3), pp. 3-26.

Diamond, P. (1971), "A model of price adjustment", Journal of Economic Theory, 3, pp. 156-168.

Elsby, M. and Michaels, R. (2013), "Marginal Jobs, Heterogeneous Firms, and Unemployment Flows", American Economic Journal: Macroeconomics, 5(1), pp. 1-48.

Foster,L.,Haltiwanger,J, andC.J.Krizan, C., .(2006) "Market Selection, Reallocation, and Restructuring in the U.S. Retail Trade Sector in the 1990s." Review of Economics and Statistics, vol 88(4), pp. 748-58.

Friedman, M. (1968). The Role of Monetary Policy. American Economic Review, vol $58(1)$, pp. $1-17$.

Hagedorn, M. and Manovskii, I. (2008), "The cyclical behavior of equilibrium unemployment and vacancies revisited", American Economic Review, 98(4), pp. 1692-1706.

Hall, R. (1979), "A theory of the natural unemployment rate and the duration of employment", Journal of Monetary Economics, 5, pp. 153-169.

Hall, R. and Milgrom, P. (2008), "The limited influence of unemployment on the wage bargain", American Economic Review, 98(4), pp. 1653-1674.

Holmlund, B. (2014), "What do labor market institutions do?", Labour Economics, forthcoming.

Hopenhayn, H. and Nicolini, J. (1997), "Optimal Unemployment Insurance", Journal of Political Economy, 105, pp. 412-438.

Hopenhayn, H. and Nicolini, J. (2009), "Optimal Unemployment Insurance and Employment History", Review of Economic Studies, 76, pp. 1049-1070.

Hornstein, A., Krusell, P. and Violante, G. (2011), "Frictional Wage Dispersion in Search Models: A Quantitative Assessment," American Economic Review, vol 101,pp. 2873-2898.

Jung, P. and Kuester, K. (2013), "Optimal Labor Market Policy in Recessions", American Economic Journals: Macroeconomics, forthcoming, 
Kennan, J. (2010), "Private Information, Wage Bargaining and Employment Fluctuations," Review of Economic Studies, 77, pp. 633-664.

Kroft, K. and Notowidigdo, M. (2011), "Should Unemployment Insurance Vary With the Unemployment Rate? Theory and Evidence", Working Paper, University of Chicago.

Landais, C. (2013), "Assessing theWelfare Effects of Unemployment Benefits Using the Regression Kink Design", Working Paper, London School of Economics.

McCall, J. (1970), "Economics of information and job search", Quarterly Journal of Economics, 84, pp. 113-126.

Menzio, G. and Shi, S. (2011), "Efficient Search on the Job and the Business Cycle," Journal of Political Economy, 119 (3), pp. 468-510.

Moene, E. (1997), "Competitive Search Equilibrium", Journal of Political Economy, 105, pp. $385-411$.

Mortensen, D. (1970), "Job search, the duration of unemployment, and the Phillips curve", American Economic Review, 60, pp. 505-517.

OECD, (2003), "The Sources of Economic Growth in OECD Countries", OECD, Paris.

Pissarides, C. (1979), "Job matching with state employment agencies and random search", Economic Journal, 89, pp. 818-833.

Pissarides, C. (2000), Equilibrium unemployment theory, ed. 2, Cambridge, MIT Press.

Pissarides, C. (2009), "The unemployment volatility puzzle: Is wage stickiness the answer?", Econometrica, 77(5), pp. 1339-1369.

Postel-Vinay, F. and Robin, J.-M. (2002b), "Wage Dispersion with Worker and Employer Heterogeneity", Econometrica, 70(6), pp. 2295-2350.

Robin, J.-M. (2011), "On the dynamics of unemployment and wage distributions", Econometrica, 79(5), pp. 1327-1355.

Rogerson, R. and Shimer, R. (2011), "Search in macroeconomic models of the labor market", Handbook of Labor Economics, Vol 4a, chap 7, Elsevier.

Shavell, S. and Weiss, L. (1979), "The Optimal Payment of Unemployment Insurance Benefits Over Time", Journal of Political Economy, 87, pp. 1347-1362.

Shimer, R. (2005), "The cyclical behavior of equilibrium unemployment and vacancies: Evidence and theory", American Economic Review, 95(1), pp. 25-49. 
Shimer, R. and Werning, I. (2007), "Reservation Wages and Unemployment Insurance", Quarterly Journal of Economics, 122(3), pp. 1145-1185.

Shimer, R. and Werning, I. (2008), "Liquidity and Insurance for the Unemployed", American Economic Review, vol 98(5), pp. 1922-1942.

Tatsiramos, K.and van Ours, J., (2013), "Labor Market Effects of Unemployment Insurance Design", Journal of Economic Surveys, forthcoming.

Wang, C. and Williamson, S. (2002), "Moral Hazard, Optimal Unemployment Insurance and Experience Rating", Journal of Monetary Economics, 49, pp. 1337-1371. 